\title{
Microwave-Assisted Adsorptive Desulfurization of Model Diesel Fuel Using Synthesized Microporous Rare Earth Metal-Doped Zeolite $Y$
}

\author{
N. Salahudeena, A.S. Ahmed, A.H. Al-Muhtasebb, B.Y. Jibrila, R. Al-Hajria, S. M. Waziria, M. Daudac, J. \\ Al-Sabahid \\ ${ }^{a}$ Department of Chemical Engineering, Ahmadu Bello University, Zaria, Nigeria. \\ ${ }^{b}$ Department of Petroleum and Chemical Engineering, College of Engineering, Sultan Qaboos University, Muscat, Oman. \\ ${ }^{c}$ Department of Mechanical Engineering, Ahmadu Bello University, Zaria, Nigeria. \\ ${ }^{d}$ Central Instrument Laboratory, College of Agricultural and Marine Sciences, Sultan Qaboos University, Muscat, Oman.
}

Received 21 November 2014; accepted 30 December 2014

\begin{abstract}
The microwave-assisted adsorptive desulfurization of model fuel (thiophene in n-heptane) was investigated using a synthesized rare earth metal-doped zeolite Y (RE Y). Crystallinity of the synthesized zeolite was 89.5\%, the silicon/aluminium (Si/Al) molar ratio was 5.2, the Brunauer-Emmett-Teller (BET) surface area was $980.9 \mathrm{~m}^{2} / \mathrm{g}$, and the pore volume and diameter was $0.3494 \mathrm{~cm}^{3} / \mathrm{g}$ and $1.425 \mathrm{~nm}$, respectively. The results showed that the microwave reactor could be used to enhance the adsorptive desulfurization process with best efficiency of $75 \%$ at reaction conditions of $100{ }^{\circ} \mathrm{C}$ and 15 minutes. The high desulfurization effect was likely due to the higher efficiency impact of microwave energy in the interaction between sulfur in thiophene and $\mathrm{HO}-\mathrm{La}(\mathrm{OSiAl})$.
\end{abstract}

Keywords: Desulfurization; Thiophene; Microwave; Diesel; Zeolite RE Y.

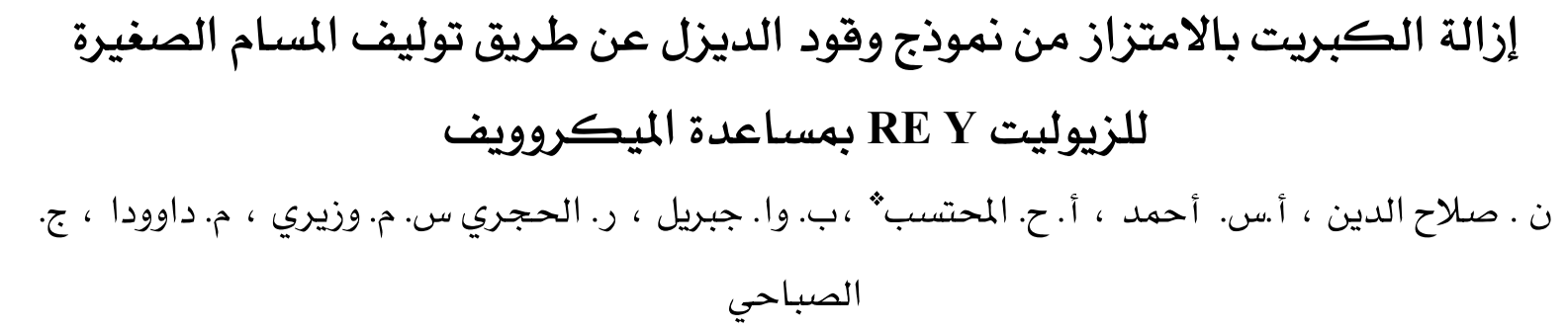

ملخص: تم فحص إزالة الكبريت بالامتزاز لنموذج وقود (ثيوفين بِّ ن- هيبتان) باستخدام توليف الزيوليت RE Y (معادن الأرض النادرة المطعهة بالزيوليت Y ). التبلور للزيوليت المولف كان 89.5 ٪. نسبة المولارية ِّ2 Si/Al كانت 5.2. وكان مساحة 980.9 BET متر مريع لكل جرام وكان حجم المسام 0.3494 سنتيمتر مكعب لكل جرام وبقطر 1.425 نانو متر. أظهرت النتائج أن تفاعل الميكروويف يمكن استخدامه لتحسين عملية الامتزاز لإزالة الكبريت

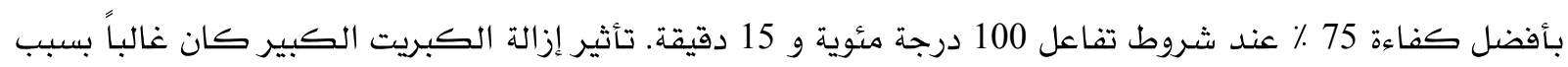
تأثير الكفاءة العالية لطاقة الميكروويف وِّ التفاعل بين الكبريت وْ الثيوفين و HO-La(OSiAl). كلمات مفتاحية: إزالة الكبريت، ثيوفين، الميكروويف، الديزل، الزيوليت RE Y. 


\section{Introduction}

Diesel fuel has become one of the most popular energy sources for driving industrial, domestic, and transportation engines due to its high efficiency (Dasgupta et al. 2013). The exponentially growing demand for diesel has increasingly heightened the environmental concerns arising from environmental pollution caused by diesel engine exhaust (Hans et al. 1989; Lin et al. 2009; Zhang et al. 2001). Diesel engine exhaust contains high levels of sulfur-containing gasses in the form of sulphur oxides $\left(\mathrm{SO}_{\mathrm{x}}\right)$, which have been identified as detrimental to human health and the environment. These detrimental effects include adverse reactions in the human respiratory system, contributions to the greenhouse effect, and acid rain. Most developed countries in the world such as the USA, Canada, and Japan, and various countries in Europe have enacted environmental regulatory policies to control sulphur levels in the diesel used by highway vehicles and restrict emissions to a bare minimum. In the USA, for instance, the Environmental Protection Agency (USEPA) has mandated a maximum sulpur content of 15 ppm in highway diesel since 2006 and, in Europe, a maximum sulphur content of 10 ppm was instituted as the EU-wide limit for diesel used in road transportation (Dasgupta et al. 2013).

Due to these increasingly stringent regulations, the desulfurization of diesel fuel has become an important research subject. An earlier industrial technique for the desulfurization of diesel was the hydro-desulfurization (HDS) process (Babich and Moulijin 2003; Duarte et al. 2011; Zannikos et al. 1995). In HDS, sulfur-containing compounds were converted to hydrogen sulfide $\left(\mathrm{H}_{2} \mathrm{~S}\right)$ and other hydrocarbons via extreme temperature and pressure conditions using hydrogen as the converter. Therefore, the HDS process was not only very expensive but was also environmentally dangerous due to the highly inflammable nature of hydrogen. Recently, several alternative, greener desulfurization processes have been proposed (Ahmad et al. 2009; Marin-Rosas et al. 2010; Salem and Hamid 1997; Seredych and Bandosz 2010; Shakirullah et al. 2009; Velu et al. 2003; Weitkamp et al. 1991).
Some of the techniques reported include extractive desulfurization (EDS), selective adsorptive desulfurization (SAD) (Subhan et al. 2012), and oxidative desulfurization (ODS) (Dharaskar et al. 2014; Lü et al. 2014; Wei et al. 2009). Some of these techniques have limitations. For instance, the extractant used in the ODS and EDS processes are usually flammable and contain volatile organic compounds (VOCs) which are also known for their environmental and safety impacts (Gao et al. 2010; Gui et al. 2010). The adsorption-based approaches appear particularly attractive due to their simpler flow sheets and lower hydrogen requirements (Ahmad et al. 2014; Dasgupta et al. 2013; Hussain et al. 2012; Sisani et al. 2014).

Due to the possibility of selective heating, microwave energy has attracted considerable attention in the field of desulphurization, where it has been found that microwave heating makes the process more effective. With microwaves, energy can be delivered to reacting molecules at a much greater rate compared to conventional heating, which is a more efficient way to heat since microwaves allow faster and more uniform heating. Ibe et al. (2007) applied microwave heating to facilitate the desulphurization of poisoned mono-nitrogen oxide $\left(\mathrm{NO}_{x}\right)$ storagereduction (NSR) catalysts. They concluded that high catalyst temperatures did not need to be reached in order to achieve the desorption of sulfur species. Therefore, the use of microwave heating provided an efficient way to promote the regeneration of the NSR catalysts. Wei et al. (2009) investigated the simultaneous desulfurization and denitrification from stimulated flue gas by a microwave reactor with potassium permanganate and zeolite. They found that the microwave reactor could be used in the oxidation of sulphur dioxide $\left(\mathrm{SO}_{2}\right)$ to sulfate with a desulphurization efficiency of $96.8 \%$. The addition of zeolite to microwave potassium permanganate increased the microwave removal efficiency of $\mathrm{SO}_{2}$ from $16.5 \%$ to $43.5 \%$. Microwave-assisted oxidative desulfurization of sour natural gas condensate via a combination of sulfuric and nitric acids was investigated by Moaseri et al. (2014). They found that that the ODS efficiency of sore condensate 


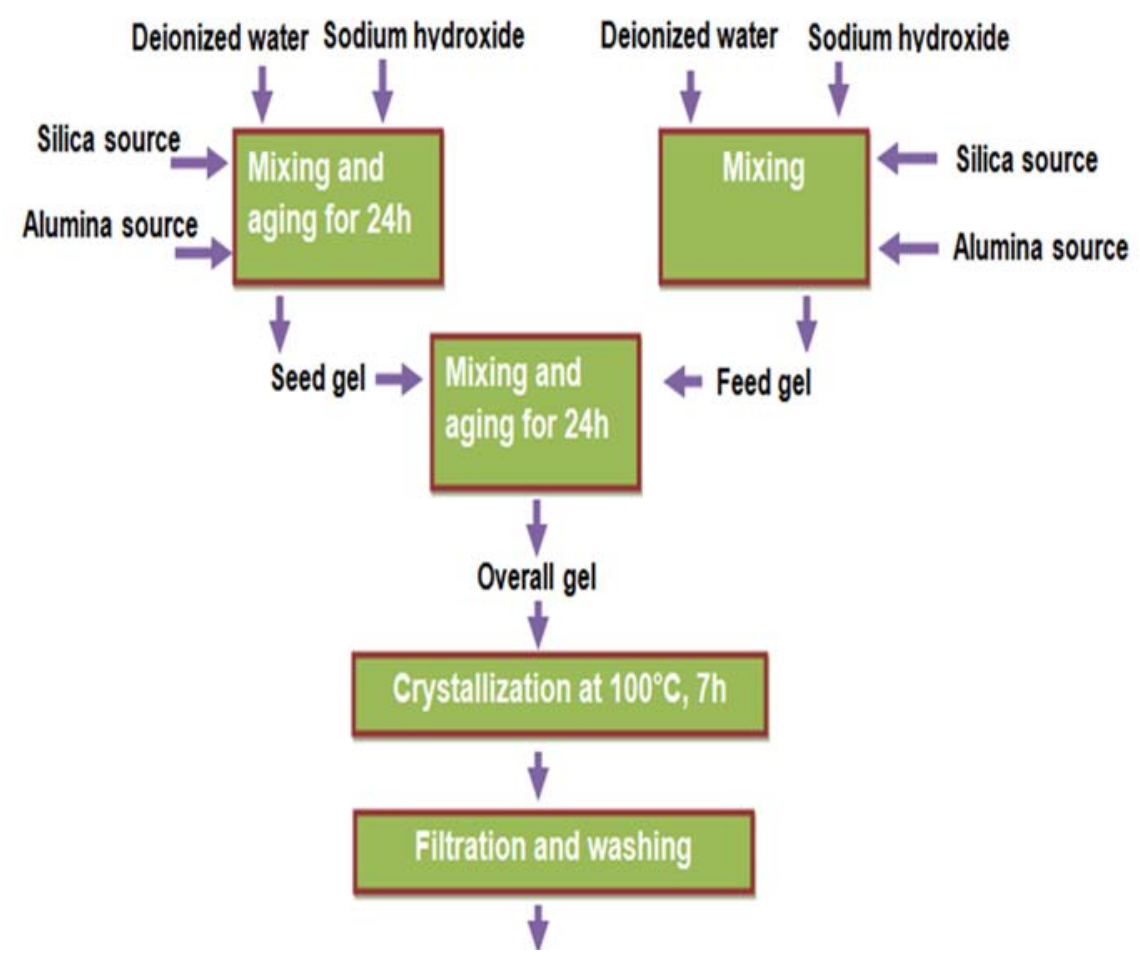

Figure 1. Flow diagram for the synthesis of zeolite $\mathrm{Y}$.

by the combination of sulfuric acid $\left(\mathrm{H}_{2} \mathrm{SO}_{4}\right)$ and nitric acid $\left(\mathrm{HNO}_{3}\right)$ was improved by $30 \%$ in the presence of microwave radiation.

This work was aimed at the desulfurization of model fuel using a cost effective and environmentally friendly technique. The suitability of a synthesized zeolite $\mathrm{Y}$ impregnated with lanthanum metal for microwave-assisted selective adsorptive desulfurization of a model fuel was investigated.

\section{Materials and Methods}

\subsection{Synthesis of Zeolite NaY}

Zeolite $Y$ in the NaY form was synthesized by adapting the verified method of the Synthesis Commission of the International Zeolite Association (Harry, 2001; Ginter et al. 1992). This process involved preparation of seed and feedstock gels, and a general gel using sodium hydroxide, sodium aluminate, aluminium hydroxide, and distilled water. This general gel was crystallized through a template-free, low temperature crystallization method inside a polypropylene bottle (Fig. 1).

\subsection{Transformation to Zeolite RE Y}

The synthesized zeolite NaY was protonated by an ion exchange reaction to make zeolite HY. A 1.0 $\mathrm{M}$ solution of $\mathrm{NH}_{4} \mathrm{Cl}$ was prepared and exchanged with zeolite $\mathrm{NaY}$ at $80{ }^{\circ} \mathrm{C}$ using a ratio of $10 \mathrm{ml}$ of solution to $1 \mathrm{~g}$ of solid and stirred for 20 minutes (Du et al. 2013; Gao et al. 2012). After the exchange reaction, the slurry was suction filtered using a vacuum pump and washed thoroughly with distilled water, then dried at $110^{\circ} \mathrm{C}$ for six hours. The zeolite HY formed was impregnated with rare earth metal (La). The reaction was carried out using an ion exchange wet-impregnation method: a $0.5 \mathrm{M}$ solution of lanthanum chloride $\left(\mathrm{LaCl}_{3}\right)$ was prepared and mixed with the protonated zeolite (HY) at $80{ }^{\circ} \mathrm{C}$ using a ratio of $12.5 \mathrm{ml}$ of solution to $1 \mathrm{~g}$ of solid and stirring the solution for one hour (Du et al. 2013; Gao et al. 2012). The product was then filtered using a vacuum pump and washed thoroughly with distilled water. The wet cake of zeolite was hydrothermally calcined at 
$650{ }^{\circ} \mathrm{C}$ in air for two hours, resulting in zeolite RE Y.

\subsection{Characterization}

X-ray diffraction (XRD) patterns were measured using a MiniFlex 600 X-ray diffractometer at $40 \mathrm{kV}$ and $10 \mathrm{~mA}$ with $\mathrm{Cu} \mathrm{Ka}$ radiation $(\lambda=0.15418 \mathrm{~nm}$ ) (Rigaku, Tokyo, Japan). The samples were scanned from $20-80^{\circ} \mathrm{C}(2 \theta)$ at a rate of $0.02{ }^{\circ} \mathrm{C} / \mathrm{min}$. X-ray fluorescence $(\mathrm{XRF})$ analysis was carried out using a MiniPal 4 X-ray fluorescence analyser (PANalytical B.V., Almelo, The Netherlands). Fourier transform infrared (FTIR) spectroscopy was applied mainly to study the chemical structure of the catalysts. The infrared spectra of the catalyst samples were measured at wavelengths ranging from 400-4000 $\mathrm{cm}^{-1}$ using a Frontier FT-IR spectrometer (PerkinElmer, Waltham, Massachusetts, USA). The morphology of the samples was analyzed with field emission scanning electron microscope JSM7600F (JEOL, Inc., Tokyo, Japan) and by a TEM1230 high contrast transmission electron microscope (TEM) (JEOL). The BET surface area and total pore volume were measured using Autosorb-1 nitrogen adsorption apparatus (Quantachrome Instruments, Boynton Beach, Florida, USA). All samples were degassed at 300 ${ }^{\circ} \mathrm{C}$ for four hours prior to the measurement.

\subsection{Desulfurization of Model Diesel}

The RE Y form of the synthesized zeolite $Y$ was used as the catalyst for the desulfurization of the model diesel using the microwave-assisted technique. The model oil used was prepared by dissolving $200 \mathrm{ppm}$ of thiophene (Sigma-Aldrich, Co., St. Louis, Missouri, USA) in n-heptane (Sigma-Aldrich) and pouring $10 \mathrm{~g}$ of model oil into the pressure vessel of a microwave reactor (Milestone, Inc., Sorisole, Italy) and $1 \mathrm{wt} \%$ of the RE Y zeolite was also added. The pressure vessel was torqued and inserted in the workstation of the reactor. The reactor's thermocouple was then inserted in the thermowell and the reactor was programmed for variable time and temperature runs. After each run, the reactor content was allowed to cool for 30 minutes. At the end of this process, the torque was loosened, and the vessel content was removed. The resulting mixture was centrifuged at 10,000 rpm for 10 minutes in an Avanti ${ }^{\mathrm{TM}} \mathrm{J}-251$ high performance centrifuge (Beckman Coulter, Brea, California, USA). The resulting raw liquid product was analysed using a Clarus 600C GC/MS system (PerkinElmer).

\section{Results and Discussion}

\subsection{Catalyst Characteristics}

Figure 2 shows the XRD patterns of the commercial and synthesized zeolite $\mathrm{Y}$. The zeolite $\mathrm{Y}$ peaks could be observed in both XRD patterns at Bragg's angles of 6, 10, 12, 16, 19, 20, 24, 27, 31, and $32^{\circ}$ (Harry 2001; Ginter et al. 1992; Treacy and Higgins, 2001). The intensities of the characteristic peaks for zeolite $Y$ at Bragg's angles of 6.13, 10.0, 11.8 , and $15.5^{\circ}$ were 1795, 718, 527 and 693 counts, respectively, for the synthesized zeolite $\mathrm{NaY}$, whereas those of the commercial zeolite $\mathrm{Y}$ were 2176, 847, 416, and 698 counts, respectively. Therefore, using the commercial zeolite $\mathrm{Y}$ as a reference, and using Equation (1) (Pal et al. 2013), the crystallinity of the synthesized zeolite $\mathrm{Y}$ was evaluated as $89.5 \%$.

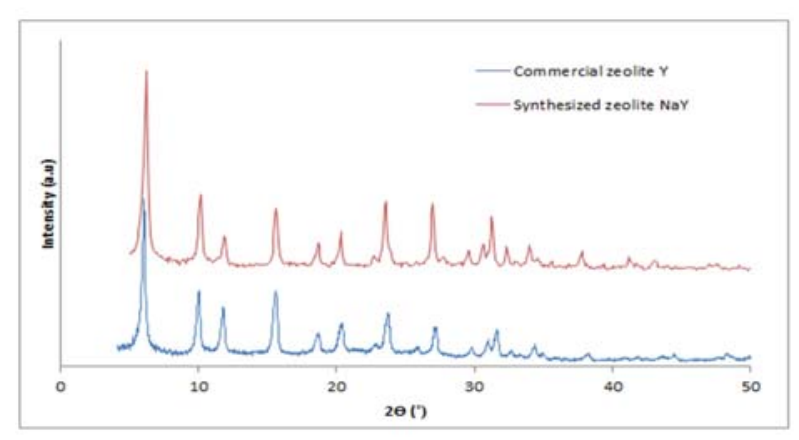

Figure 2. XRD patterns of the synthesized and commercial zeolite $\mathrm{Y}$.

Table 1 presents the XRF result of the synthesized zeolite $\mathrm{Y}$, reflecting the fact that the zeolite contained low concentrations of impurities, with a measurement generally below $1 \mathrm{wt} \%$. The $\mathrm{Si} / \mathrm{Al}$ molar ratio was 5.2 and the loss on ignition (LOI) was $26 \mathrm{wt} \%$.

Figures 3a-d show the structural mophology of the synthesized zeolite $\mathrm{NaY}$ at magnifications of $8,000,15,000,30,000$, and 45,000, respectively. The macrographs show that the zeolite $\mathrm{Y}$ at magnifications of 100,000, 200,000, 300,000 and 400,000 times. The clear boundary shapes of the crystals are very obvious. Although the crystal 
Crystallinity $=\frac{\text { Intensity of the characteristic XRD peak of the product }}{\text { Intensity of the characteristic peak of the reference XRD pattern }} \times 100$

Table 1. Chemical composition of the synthesized zeolite $\mathrm{Y}$.

\begin{tabular}{cc}
\hline Metal oxides & $\mathbf{W t} \%$ \\
\hline $\mathrm{Al}_{2} \mathrm{O}_{3}$ & 17.98 \\
$\mathrm{SiO}_{2}$ & 54.75 \\
$\mathrm{~K}_{2} \mathrm{O}$ & 0.04 \\
$\mathrm{CaO}$ & 0.27 \\
$\mathrm{TiO}_{2}$ & 0.09 \\
$\mathrm{Cr}_{2} \mathrm{O}_{3}$ & 0.04 \\
$\mathrm{MnO}$ & 0.03 \\
$\mathrm{Fe}_{2} \mathrm{O}_{3}$ & 0.3 \\
$\mathrm{CuO}$ & $\mathrm{ND}$ \\
$\mathrm{LOI}$ & 26 \\
\hline
\end{tabular}

ND: Not determined
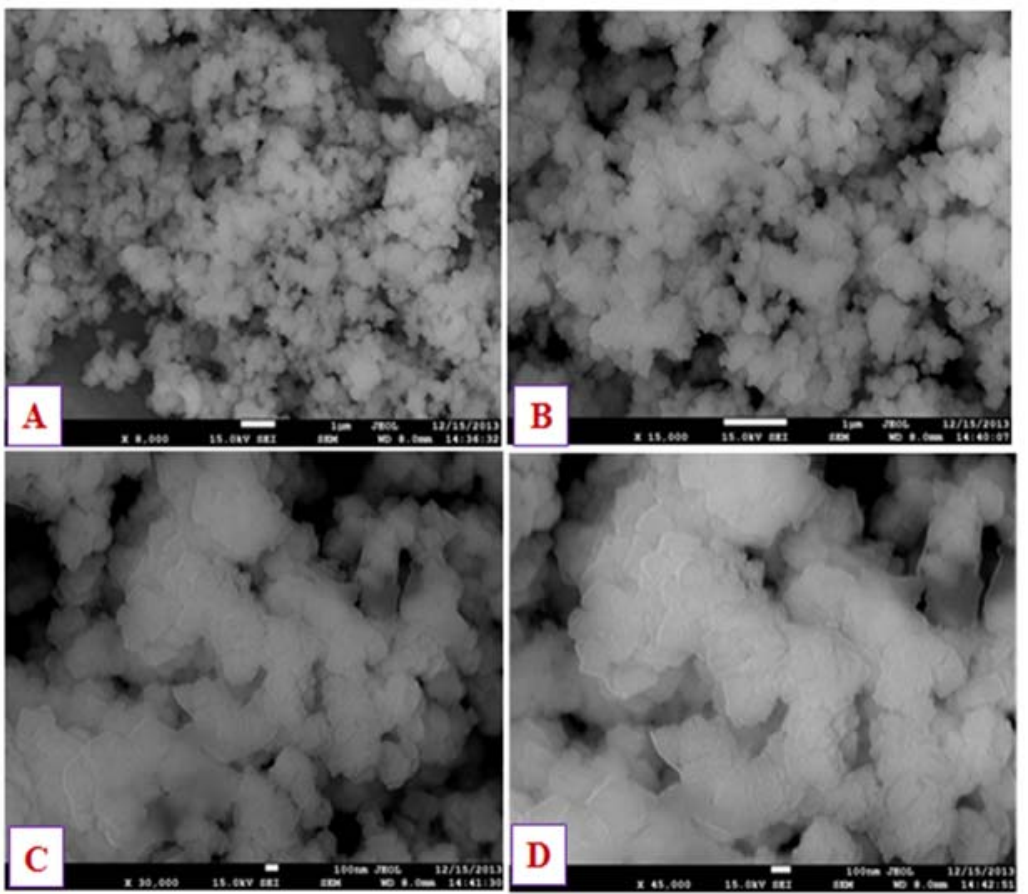

Figure 3. SEM images for the synthesized zeolite NaY at various magnifications: (A) 8000; (B) 15000; (C) 30000 and (D) 45000. 
Table 2. BET results for the synthesized zeolite Y.

\begin{tabular}{cccc}
\hline Sample & Surface Area $\left(\mathrm{m}^{2} / \mathrm{g}\right)$ & Pore Volume $\left(\mathrm{cm}^{3} / \mathrm{g}\right)$ & Pore Diameter $(\AA)$ \\
\hline -synthesized & 980.9 & 0.3494 & 14.25 \\
Commercial & 601.8 & 0.2500 & 16.40 \\
\hline
\end{tabular}
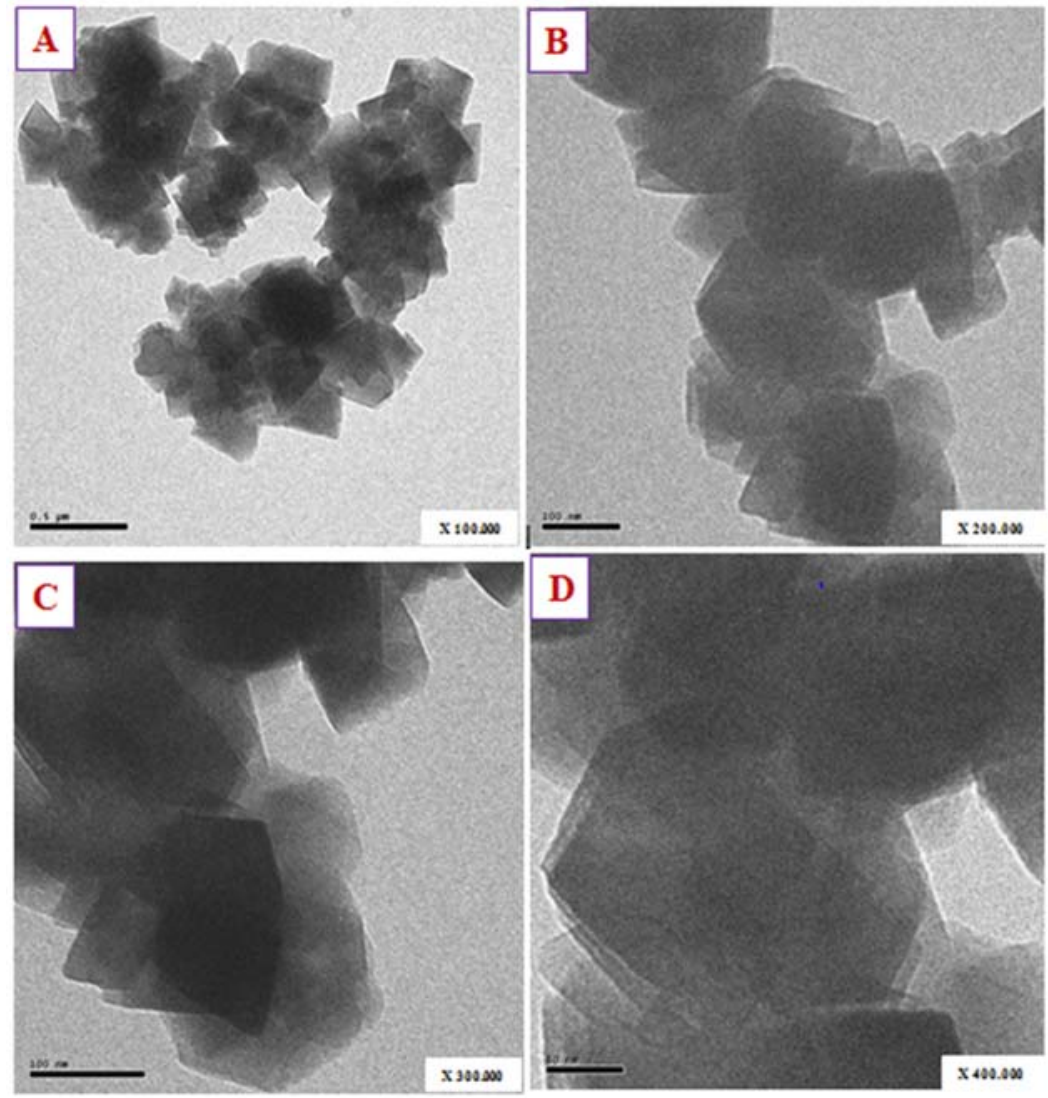

Figure 4. TEM images for the synthesized zeolite NaY at various magnifications: (A) 100000; (B) 200000; (C) 300000 and (D) 400000 .

average crystal size was estimated as $200 \mathrm{~nm}$. Figure 4 also shows the TEM images of the synthesized zeolite $\mathrm{Y}$ at magnifications of 100,000 , 200,000, 300,000 and 400,000 times. The clear boundary shapes of the crystals are very obvious. Although the crystal images overlap extensively, the boundary edges of the unit tetrahedral crystal shape is obvious. The average crystal size was estimated as $200 \mathrm{~nm}$.

BET analysis for the synthesized and commercial zeolite $\mathrm{Y}$ shows that the specific surface area of the synthesized zeolite $\mathrm{Y}$ was $63 \%$ higher and the pore volume was $40 \%$ higher than that of the commercial zeolite $\mathrm{Y}$ (Table 2). However, the pore diameter of the commercial zeolite $\mathrm{Y}$ was $15 \%$ higher than that of the synthesized zeolite $\mathrm{Y}$.

\subsection{Desulfurization of Model Diesel}

The sulfur reduction at variable reaction times and temperatures for the microwave-assisted desulfurization of model petroleum oil using the prepared zeolite RE Y catalyst is shown in Figs. 5 and 6, respectively. Figure 5 shows the sulfur 
reduction for reactions carried out at $100{ }^{\circ} \mathrm{C}$ at variable times. The maximum sulfur reduction was observed at 15 minutes when the sulphur reduction was $74 \%$. Figure 6 shows the sulfur reduction for the reactions carried out at 10 minutes for variable temperatures. There was a continuous progressive increase in sulfur reduction throughout the runs, with the maximum sulphur reduction $(74 \%)$ occurring at $150{ }^{\circ} \mathrm{C}$.

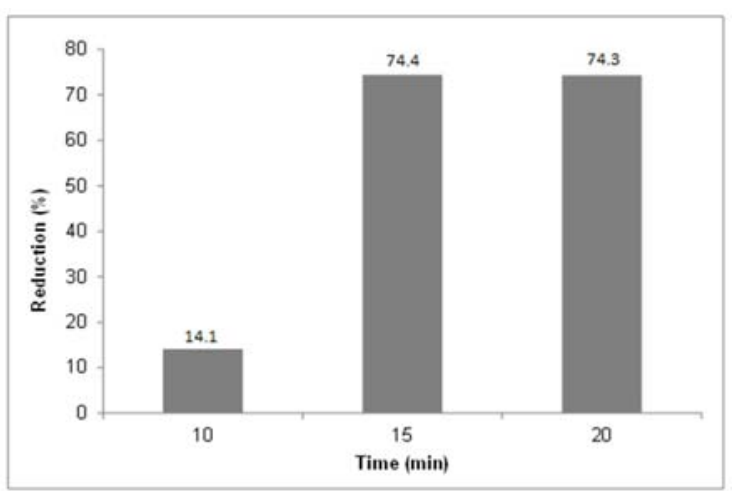

Figure 5. Trend of microwave desulfurization of model diesel at variable time.

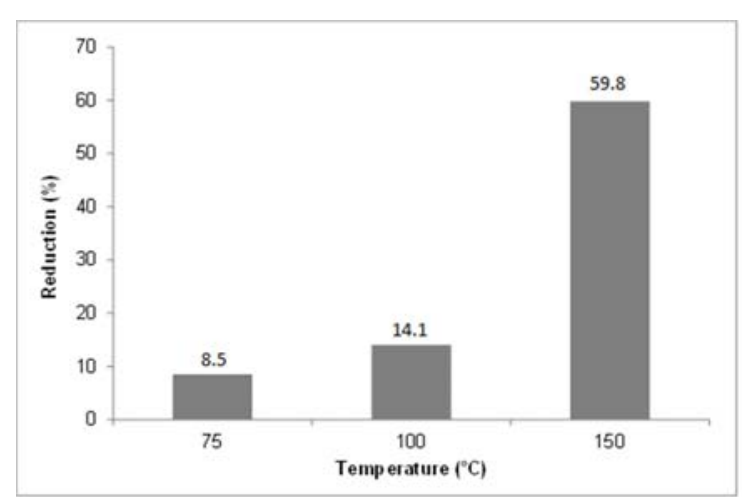

Figure 6. Trend of microwave desulfurization of model diesel at variable temperature.

Figures 7 and 8 show the FTIR spectra of the synthesized catalyst before and after the reaction. The spectra were similar except that the spent zeolite showed the presence of strange bands at wavelengths 1450 and $2930 \mathrm{~cm}^{-1}$ for both the variable temperatures and time curves. These bands were due to the adsorption of sulfur (Song et al. 2013) and were completely absent in the fresh catalyst spectrum. It could also be observed that for the variable time runs, the sample at 15 minutes showed a larger band area while for the variable temperature runs, the sample at $150{ }^{\circ} \mathrm{C}$ showed the largest band area. Hence, the synthesized catalyst showed a potent effect on the desulfurization of the model diesel fuel, while the FTIR analysis of the catalyst before and after the reactions showed that the mode of desulphurization employed by the catalyst was adsorptive desulfurization. The extent of desulfurization recorded by this work compares closely with the work of Fallah et al. (2015), who reported using a different approach.

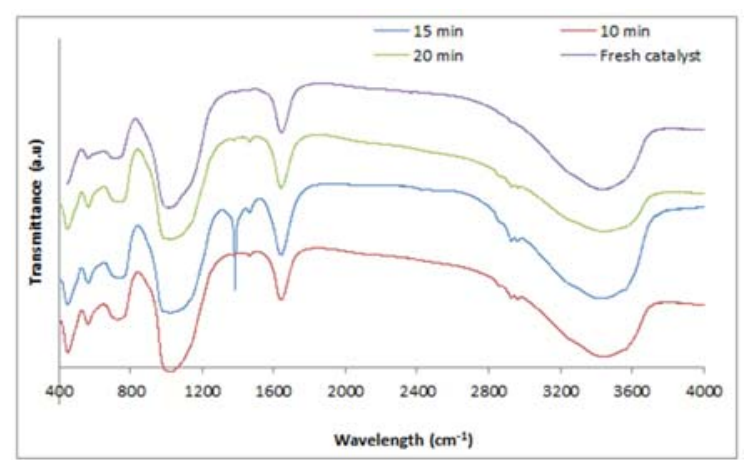

Figure 7. FTIR spectra of the fresh and used catalysts for the desulfurization at variable time.

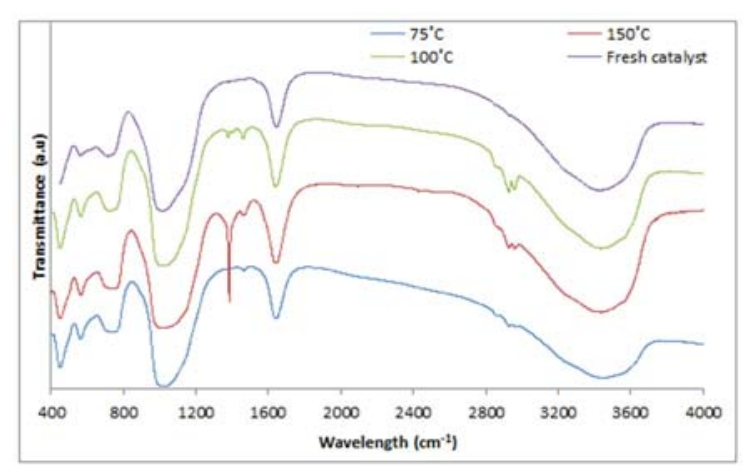

Figure 8. FTIR spectra of the fresh and used catalyst for the desulfurization at variable temperatures.

\section{Conclusions}

A microporous zeolite $\mathrm{Y}$ having $89.5 \%$ crystallinity, a $980.9 \mathrm{~m}^{2} / \mathrm{g}$ surface area, a 0.3494 $\mathrm{cm}^{3} / \mathrm{g}$ pore volume, and a $200 \mathrm{~nm}$ crystal size was synthesized. The $\mathrm{Si} / \mathrm{Al}$ molar ratio of the synthesized zeolite was 5.2 and the LOI was $26 \%$. The synthesized zeolite was effective for adsorptive desulfurization of a model fuel, having the best efficiency of $75 \%$ in a microwave-assisted desulfurization carried out at $100{ }^{\circ} \mathrm{C}$ for 15 minutes. The high desulfurization effect was likely 
due to the higher efficiency impact of microwave energy in the interaction between sulfur in thiophene and HO-La(OSiAl).

\section{Acknowledgments}

The authors gratefully acknowledge the financial and technical support of the Petroleum Development Trust Fund (PDTF) of Abuja, Ahmadu Bello University in Zaria and the College of Engineering at Sultan Qaboos University in Oman.

\section{References}

Ahmad W, Ahmad I, Ishaq M, Ihsan K (2014), Adsorptive desulfurization of kerosene and diesel oil by $\mathrm{Zn}$ impregnated montmorollonite clay. Arabian Journal of Chemistry, In Press.

Babich IV, Moulijn JA (2003), Science and technology of novel processes for deep desulfurization of oil refinery streams: A review. Fuel 82:607-631.

Dasgupta S, Gupta, PA, Nanoti A, Goswami AN, Garg MO, Tangstad E, Vistad OB, Karlsson A, Stöcker M (2013), Adsorptive desulfurization of diesel by regenerable nickel based dsorbents. Fuel, 108:184-189.

Dharaskar SA, Wasewar KL, Varma MN, Shende DZ, Tadi KK, Yoo CK (2014), Synthesis, characterization, and application of novel trihexyl tetradecyl phosphonium bis $(2,4,4$ trimethylpentyl) phosphinate for extractive desulfurization of liquid fuel. Fuel Processing Technolog 123:1-10.

Du X, Zhang, Li X, Tan Z, Liu H, Gao X (2013), Cation location and migration in lanthanumexchanged $\mathrm{NaY}$ zeolite. Chinese Journal of Catalysis 34:1599-1607.

Duarte FA, Mello PA, Bizzi CA, Nunes MAG, Moreira EM, Alencar MS, Motta HN, Dressler V, Flores EM (2011), Sulfur removal from hydrotreated petroleum fractions using ultrasound-assisted oxidative desulfurization process. Fuel 90,:2158-2164.

Fallah RN, Azizian S, Dwivedi AD, Sillanpää M (2015), Adsorptive desulfurization using different passivated carbon nanoparticles by PEG-200. Fuel Processing Technology 130:214223.
Gao HS, Guo C, Xing JM, Zhao JM, Liu HZ (2010), Extraction and oxidative desulfurization of diesel fuel catalyzed by a Brønsted acidic ionic liquid at room temperature. Green Chemistry 12:1220-1224.

Gao X, Qin Z, Wang B, Zhao X, Li L, Zhao H, Liu H, Shen B (2012), High silica REHY zeolite with low rare earth loading as high-performance catalyst for oil conversion. Applied Catalysis A: Genetics 413:254-260.

Ginter DM, Bell A, Radke CJ (1992), Synthesis of Microporous Materials, Molecular Sieves, Vol. 1. New York: Van Nostrand Reinhold 6.

Gui JZ, Liu D, Sun ZL, Liu DS, Min D, Song B, Peng XL (2010), Deep oxidative desulfurization with task-specific ionic liquids: An experimental and computational study. Journal of Molecular Catalysis A: Chemical 331:64-70.

Hans B, Annemie B, Gerd E, Ruud S, Julian RHR (1989), Lithium-vanadium bronzes as model catalysts for the selective reduction of nitric oxide. Catalysis Today 4:139-154.

Harry R (2001), Verified synthesis of zeolitic materials; Linde Type Y, Synthesis Commission of the International Zeolite Association. Amsterdam: Elsevier.

Hussain M, Abbas N, Fino D, Russo N (2012), Novel mesoporous silica supported $\mathrm{ZnO}$ adsorbents for the desulfurization of biogas at low temperatures. Chemical Engineering Journal 188:222-232.

Ibe M, Gomez S, Malinger KA, Fanson P, Suib SL (2007), Microwave-assisted desulfurization of NOx storage-reduction catalyst. Applied Catalysis B: Environmental 69:235-239.

Lin ZZ, Niu H, He H, Ji Y (2009), Simultaneous desulfurization and denitrification by microwave reactor with ammonium bicarbonate and zeolite. Journal of Hazardous Materials 162:837-841.

Lü H, Deng C, Renb W, Yang X (2014), Oxidative desulfurization of model diesel using $\left[\left(\mathrm{C}_{4} \mathrm{H}_{9}\right)_{4} \mathrm{~N}_{6} \mathrm{Mo}_{7} \mathrm{O}_{24}\right.$ as a catalyst in ionic liquids. Fuel Processing Technology 119:87-91.

Marin-Rosas C, Ramirez-Verduzco LF MurrietaGuevara FR, Hernandez-Tapia G, RodriguezOtal LM (2010), Desulfurization of low sulfur diesel by adsorption using activated carbon: Adsorption isotherms. Industrial \& Engineering Chemistry Research 49: 4372-4376.

Moaseri E, Shahsavand S, Bazubandi B (2014), Microwave-assisted oxidative desulfurization of 
sour natural gas condensate via combination of sulfuric and nitric acids. Energy \& Fuels 28:825-831.

Pal P, Das JK, Das N, Bandyopadhyay S (2013), Synthesis of $\mathrm{NaP}$ zeolite at room temperature and short crystallization time by sonochemical method. Ultrasonics Sonochemistry 20:314-321.

Salem AB, Hamid HS (1997), Removal of sulfur compounds from naphtha solutions using solid adsorbents. Chemical Engineering \& Technology 20:342-347.

Seredych M, Bandosz TJ (2010), Adsorption of dibenzothiophenes on nanoporous carbons: Identification of specific adsorption sites governing capacity and selectivity. Energy \& Fuels 24:3352-3360.

Shakirullah S, Ahmad I, Ishaq M, Ahmad W (2009), Study on the role of metal oxides in desulfurization of some petroleum fractions. Journal of the Chinese Chemical Society 56:107114.

Sisani E, Cinti G, Discepoli G, Penchini D, Desideri U, Marmottini F (2014), Adsorptive removal of $\mathrm{H}_{2} \mathrm{~S}$ in biogas conditions for high temperature fuel cell systems. International Journal of Hydrogen Energy, In Press.

Song H, Wan X, Dai M, Zhang J, Li F, Song H (2013), Deep desulfurization of model gasoline by selective adsorption over $\mathrm{Cu}-\mathrm{Ce}$ bimetal ionexchanged $Y$ zeolite. Fuel Processing Technology 116:52-62.
Subhan F, Liu BS, Zhang Y, Li XG (2012), High desulfurization characteristic of lanthanum loaded mesoporous MCM-41 sorbents for diesel fuel. Fuel Processing Technology 97:71-78.

Treacy MMJ, and Higgins JB (2001), Collection of simulated XRD powders for zeolites, published on behalf of the Synthesis Commission of the International Zeolite Association. Amsterdam: Elsevier.

Velu S, Ma X, Song C (2003), Selective adsorption for removing sulfur from jet fuel over eolitebased adsorbents. Industrial and Engineering Chemical Research 42:5293-5304.

Wei Z, Niu H, Ji Y (2009), Simultaneous removal of $\mathrm{SO}_{2}$ and $\mathrm{NOx}$ by microwave with potassium permanganate over zeolite. Fuel Processing Technology 90:324-329.

Weitkamp J, Schwark M, Ernst S (1991), Removal of thiophene impurities from benzene by selective adsorption in zeolite ZSM-5. Journal of Chemical Society, Chemical Communications, 1133-1134.

Zannikos F, Lois E, Stournas S (1995), Desulfurization of petroleum fractions by oxidation and solvent extraction. Fuel Processing Technology 42:35-45.

Zhang XL, Hayward DO, Lee CD, Mingos DMP (2001), Microwave-assisted catalytic reduction of sulfur dioxide with methane over $\mathrm{MoS}_{2}$ catalysts. Applied Catalysis B: Environmental 33:137-148. 